\title{
Flexibility in timing of molting of fiddler crab megalopae: evidence from in situ manipulation of cues
}

\author{
Nancy J. O'Connor ${ }^{1, *}$, Michael L. Judge ${ }^{2}$ \\ ${ }^{1}$ Department of Biology, University of Massachusetts Dartmouth, N. Dartmouth, Massachusetts 02747-2300, USA \\ ${ }^{2}$ Department of Biology, Manhattan College, Riverdale, New York 10471, USA
}

\begin{abstract}
Rather than relying on chance delivery of larvae to experimental field substrata, we developed a field caging method to expose lab-reared crab megalopae to natural cues that could affect timing of molting to the first crab stage. Uca pugnax megalopae were placed in plastic mesh cages containing freshly collected sediments from a marsh occupied by $U$. pugnax, or similar sediments that had been combusted to remove organic material. Cages of each sediment type were placed at identical tidal elevations in a Spartina alterniflora marsh for 1 or $3 \mathrm{~d}$ of exposure to natural seawater. Significantly more megalopae molted in cages containing fresh than combusted marsh sediments $190 \%$ vs $32 \%$, ANOVA $F_{1,8}=53.95, \mathrm{p}<0.001$ ) after a $3 \mathrm{~d}$ penod of exposure. Three days after the $1 \mathrm{~d}$ exposure period, nearly all megalopae from cages of both sediment types had molted. Furthermore, all sibling megalopae remaining in the lab during the field experiment failed to molt. High rates of molting of megalopae caged in the marsh with natural and combusted sediments indicate that chemical substances both in the water overlying the marsh and associated with marsh sediments stimulated molting of megalopae.
\end{abstract}

KEY WORDS: Fiddler crab $\cdot$ Uca pugnax $\cdot$ Larvae $\cdot$ Molting $\cdot$ Chemical cues

\section{INTRODUCTION}

Research on settlement and metamorphosis of decapod postlarvae has documented a behavioral response of postlarvae to cues in the field, evidenced by preferential settlement in certain areas, and a physiological response to cues in the lab, evidenced by earlier molting to the benthic stage in the presence of certain cues. During settlement in the field, decapod postlarvae often respond to particular habitat features. For example, spiny lobster postlarvae prefer to settle in clumps of branched red algae (Herrnkind \& Butler 1986), Dungeness crab megalopae settle in higher numbers onto bivalve shell debris than onto sediments (Fernandez et al. 1993, Eggleston \& Armstrong 1995), and newly settled blue crab megalopae are found in greater abun-

•E-mail: noconnor@umassd.edu dance within seagrass beds or intertidal marshes than in unvegetated areas (Orth \& van Montfrans 1987. Mense \& Wenner 1989). Fiddler crab megalopae settle in salt marshes but not adjacent tidal flats, and are found in greater abundance in areas inhabited by older conspecifics (O'Connor 1993).

Habitat characteristics may also affect the timing of metamorphosis. In the laboratory, fiddler crab megalopae molt to the first crab stage sooner in the presence of particular habitat components. Uca pugilator megalopae respond (by molting earlier) to sediments collected near adult burrows (Christy 1989) or to natural sediments maintained with adult crabs $\left(\mathrm{O}^{\prime}\right.$ Connor 1991). Uca pugnax megalopae molt in response to chemicals released by adults, but not to mock sediments (silt-sized glass beads) that were maintained in the presence of adult crabs $1 \mathrm{O}^{\prime}$ Connor \& Gregg unpubl.). Yet we do not know how megalopae respond physiologically, by molting, in response to natural cues in the field. 
We have developed and tested a method to place equal numbers of sibling, laboratory-reared larvae into the field, enclosed in mesh cages, for exposure to different types of potential habitat cues. The method facilitates easy retrieval of cages and subsequent examination of enclosed animals. Other advantages of our method are that the larvae have had no prior exposure to natural cues in the field, they have been reared under identical conditions, they are of known ages and competent to settle and metamorphose, and we do not have to rely on chance transport of larvae to experimental substrata. In addition, the responses of larvae to complex cues in the field can be compared directly with those of larvae exposed to single cues in the laboratory.

The present study examined the effects of 2 potential habitat cues on timing of molting of $U_{C a}$ pugnax megalopae in the field. The first cue was the natural seawater overlying the surface of a salt marsh inhabited by $U$. pugnax (representing waterborne cues). The second cue was the sediments freshly collected from the marsh surface (= benthic cues). Although both cues individually affected the timing of molting, the greatest response to these complex habitat cues occurred when waterborne and benthic cues were combined

\section{MATERIALS AND METHODS}

Larval culture. Larvae used in the experiments were released by ovigerous female Uca pugnax collected from the Slocums River estuary in S. Dartmouth, Massachusetts, USA (salinity approx. 30) in June 1995. Additional larvae were obtained from crabs that were maintained in the laboratory and periodically checked for the presence of eggs. Ovigerous crabs were placed individually in $11.5 \mathrm{~cm}$ glass culture dishes with $-200 \mathrm{ml}$ filtered $(0.45 \mu \mathrm{m})$ seawater diluted with deionized water to a salinity of 25 (= FSW), to which the antibiotics sodium penicillin $\mathrm{G}\left(21.9 \mathrm{mg} \mathrm{l}^{-1}\right)$ and streptomycin sulfate $\left(36.5 \mathrm{mg} \mathrm{l}^{-1}\right)$ were added. Each morning the dishes were checked for the presence of larvae. If larvae had not hatched, the ovigerous females were transferred to a clean bowl with fresh FSW and antibiotics. The crabs were not fed.

Newly released sibling zoeae were placed in groups of -40 in each of 3 or 4 culture dishes (diam. $11.5 \mathrm{~cm}$ ). Each dish contained $\sim 175 \mathrm{ml}$ of FSW and antibiotics. The zoeae were offered the rotifer Brachionus plicatilis and newly hatched brine shrimp nauplii (Artemia sp.) as food. As the zoeae molted to later stages, the proportion of rotifers in their diet was decreased, and that of Artemia was increased. By the time they reached the fourth zoeal stage, the larvae were fed brine shrimp only. Each day the larvae were transferred to a clean dish with fresh FSW and antibiotics, and food was added. The number of deaths was noted, and the proportion of individuals molting (evidenced by the presence of exuviae) was approximated. Mortality was generally very low $(<5 \%)$, and larvae tended to molt synchronously. Both ovigerous females and larval cultures were maintained in an environmental chamber $\left(26^{\circ} \mathrm{C} \pm 1{ }^{\circ} \mathrm{C}, 14 \mathrm{~h}\right.$ light: $10 \mathrm{~h}$ dark photoperiod).

After molting to the megalopa stage (usually after 11 to $13 \mathrm{~d}$ of larval life), the larvae were cultured in groups of 25 to 80 in $20 \mathrm{~cm}$ glass culture dishes containing $600 \mathrm{ml} F S W$, antibiotics, and Artemia nauplii. Megalopae were transferred and fed each day. Six days after they had molted to the megalopa stage, megalopae were transferred to the field site

Cage design. Cylindrical cages $(10 \mathrm{~cm}$ height $x$ $8.8 \mathrm{~cm}$ width) were used for field deployment of labreared larvae. The base of the cage consisted of the bottom portion $(8.8 \mathrm{~cm}$ width $\times 1.4 \mathrm{~cm}$ height $)$ of a polystyrene petri dish (Baxter D1906). The sides and top of the cages were made of $300 \mu \mathrm{m}$ nylon mesh. The top contained a flap that opened halfway to allow addition of megalopae in the field. All seams of the cage were glued with $100 \%$ silicone sealant (G.E. \#012). A $15 \mathrm{~cm}$ mild steel (high carbon) stake was glued to the outside of the bottom of the petri dish to secure the cage in benthic sediments in the field.

Field site. The field site was a marsh consisting of Spartina alterniflora and Salicornia europaea growing in muddy sand sediments $(75 \%$ particles $>63 \mu \mathrm{m})$, located in Demarest Lloyd State Park near the mouth of the Slocums River estuary in Dartmouth, Massachusetts, USA $\left(41^{\circ} 31^{\prime} \mathrm{N}, 70^{\circ} 59^{\prime} \mathrm{W}\right)$. The marsh contained numerous burrows occupied by the fiddler crab $U_{c a}$ pugnax.

Treatments and cage deployment. Cages contained $15 \mathrm{ml}$ of sediments of 1 of 2 types: (1) surface $1-0.5 \mathrm{~cm}$ depth) marsh sediments freshly collected near fiddler crab burrows (= fresh marsh sediments treatment), and (2) identical marsh sediments that had been dried and combusted in a muffle furnace $\left(550\right.$ to $600^{\circ} \mathrm{C}$ for $2 \mathrm{~h}$ ) to oxidize organic material (= muffled marsh sediments treatment). Large detrital fragments and pebbles were removed from both sediment types. Both sediment types were placed in cages in the field just before addition of larvae.

Within the marsh, a transect parallel to the shore was established at a tidal height of $0.9 \mathrm{~m}$, the elevation of the marsh where crabs were abundant. Ten cages, each separated by $50 \mathrm{~cm}$, were placed along the transect. Cages alternated between fresh and muffled sediment types. All cages in the marsh were $\geq 3 \mathrm{~m}$ into the vegetated habitat.

Experiments began $6 \mathrm{~d}$ after the fiddler crab larvae had reached the megalopa stage. In the first experi- 
ment, cages were deployed on 13 July and retrieved on 14 July 1995 (20 h in the field with $\sim 10$ h of submersion; = 1-day deployment; Fig. 1). The second experiment took place from 14 July to 17 July 1995 (70 h in the field with $\sim 28 \mathrm{~h}$ of submersion: $=3$-day deployment).

Six-day old megalopae pooled from 3 different broods were divided into groups of 10 and placed in $12 \mathrm{ml}$ of FSW (salinity = 25) in polypropylene centrifuge tubes for transport to the field site. Some Artemia nauplii were added to provide food for the megalopae. Megalopae were introduced into each cage during late afternoon $\sim 3 \mathrm{~h}$ prior to submersion by the incoming tide. Megalopae were rinsed from the centrifuge tube into the cage using sieved, field-collected seawater. The opening at the top of the cage was then sealed with silicone.

Cages were monitored during daylight hours. One of the fresh sediment cages in the marsh was displaced $\sim 0.5 \mathrm{~m}$ landward and reanchored on the second day of the 3 -day deployment. Because air temperatures ranged from $20^{\circ} \mathrm{C}$ at night to $32^{\circ} \mathrm{C}$ during the day, additional seawater was added to cages of the 3-day deployment after $48 \mathrm{~h}$. Daytime water temperature in the vicinity of the field site, however, never exceeded $26^{\circ} \mathrm{C}$. Salinity of water at the site was $\sim 28$ to 30

Laboratory observations. Sixteen siblings of the megalopae used in the 3-day deployment were maintained simultaneously in the laboratory in a $11.5 \mathrm{~cm}$ culture dish containing FSW (salinity $=25$ ) with antibiotics. Each day the number of individuals that had molted to the first crab stage was noted. The remaining meglaopae were transferred to a clean dish with fresh FSW and Artemia.

Subsequent to the field deployments, the effect on molting time of muffled sediments as a potential tactile cue was examined in the laboratory. Four days after molting to the megalopa stage, larvae were placed individually into $60 \times 15 \mathrm{~mm}$ sterile polystyrene petri dishes containing $10 \mathrm{ml}$ FSW or $10 \mathrm{ml}$ FSW plus $0.5 \mathrm{ml}$ muffled sediments from the same stock used in the field experiments. Twenty megalopae were tested in each treatment. Several Artemia nauplii were added as food for the megalopae. Each day the number of individuals molting to the first $\mathrm{crab}$ stage was noted, and megalopae were transferred to new dishes containing fresh treatments every other day.

Data analysis. The proportion molting to the first crab stage within each replicate cage was the response variable. After arcsine transformation, the variances were found not to differ significantly from homogeneity (Bartlett's test $=0.47, p=0.52$ ). Data from each field
Predicted Tidal Series, July 1995

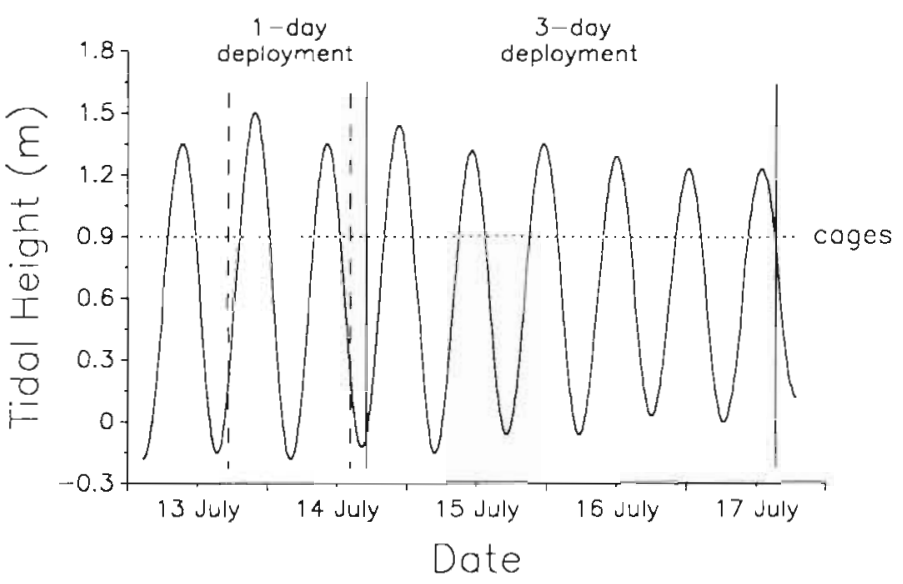

Fig. 1. Tidal series at the field site during the 1-day (vertical dashed lines) and the 3-day (vertical solid lines) deployment study periods. Tidal heights were calculated from the predicted tidal levels for Newport, Rhode Island, USA (NOAA 1995) and adjusted from measurements conducted at the site. The horizontal dotted line indicates the tidal height of the experimental cages. Megalopae were submerged by the tide $47.5 \%$ of the time during the 1 -day and $39.7 \%$ during the 3 -day deployment

deployment were analyzed via 1-way ANOVA with sediment as the main effect.

The effect of the presence of muffled sediments on timing of molting in the lab was analyzed by comparing the median day of molting of megalopae in each treatment using the non-parametric Mann-Whitney $U$ test, due to the non-normal distribution of the data.

\section{RESULTS}

Very few megalopae molted to the first crab stage during the 1 -day deployment in the marsh habitat: an average of $2 \%$ molted in cages with the muffled sediment and $0 \%$ in the fresh sediment treatments (Fig. 2). However, after $3 \mathrm{~d}$ in the marsh, significantly more megalopae molted in cages containing the fresh sediment treatment (Fig. 2; mean proportion $\pm \mathrm{SD}=0.90 \pm$ $0.07)$ than in the muffled sediment treatment $(0.32 \pm$ 0.11 ) (ANOVA, $F_{1,8}=53.95, \mathrm{p}<0.001$ ). Survivorship of megalopae in cages in the marsh habitat was very high: 90 to $100 \%$ in each cage survived the 1-day and 3-day deployment periods.

Megalopae from the fresh and muffled sediment cages placed in the marsh for the 1-day deployment were removed from the cages at the end of the deployment, and held in a plastic container containing FSW in the laboratory. One day after removal from the marsh, only $\sim 10 \%$ had molted to first crab. Three days after field exposure, however, 80 to $90 \%$ of the mega- 


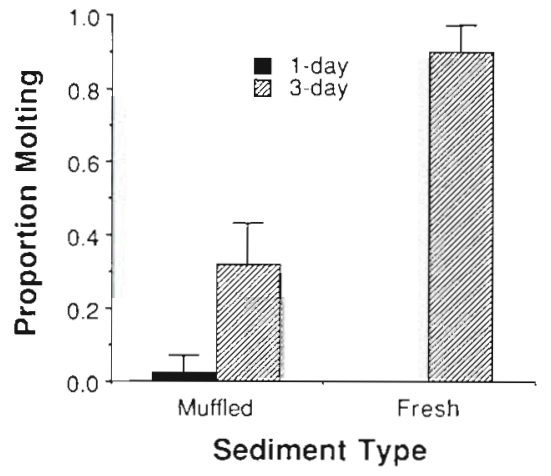

Fig. 2. Uca pugnax. Proportion (mean \pm SD) of fiddler crab megalopae molting to first crab stage within marsh (Spartina alternifloral habitats during 2 field deployments. Although proportion molting during the 1-day deployment did not differ between sediment treatments, the proportion molting within 5 replicate cages during the 3-day deployment was significantly greater (ANOVA on arcsine-transformed data, $F_{1, \text { ४ }}=53.95, \mathrm{p}<0.001$ ) for sediment freshly collected from nearby fiddler crab burrows than similar sediment that had been previously combusted in a muffle furnace (2 to $3 \mathrm{~h}$ at 550 to $600^{\circ} \mathrm{C}$ ). Survivorship of individuals was greater than $90 \%$ during both deployments

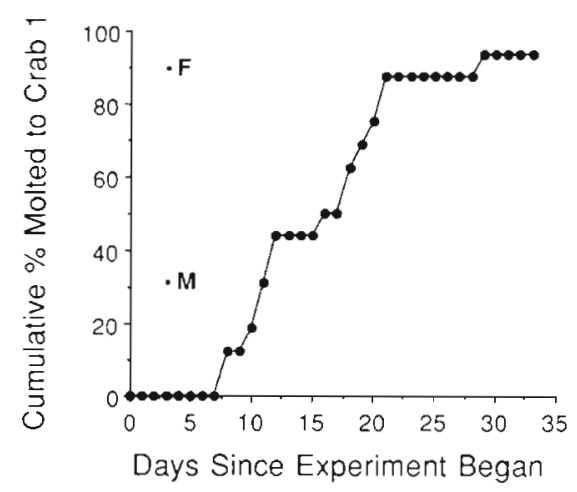

Fig. 3. Uca pugnax. Cumulative molting frequency of fiddler crab megalopae maintained in the laboratory without field cues. Sixteen 6 -day-old megalopae from the same broods utilized in the field expenment were scored daily for number molting to crab 1, commencing with initiation of the 3-day deployment. The corresponding mean molting percentage in the field during the 3-day deployment is indicated by ' $F$ ' (fresh sediment) and ' $M$ ' (muffled sediment)

lopae molted to the first crab stage, which is comparable to the percentage molting during the 3-day period of exposure to natural cues in the field.

Megalopae maintained in the laboratory molted far more slowly than their siblings in the field. At the end of the 3-day field deployment, none of the specimens in the lab had molted to the first crab stage (Fig. 3). Even $1 \mathrm{wk}$ after the field experiment ended, only $19 \%$ of the megalopae in the lab had molted
In the laboratory, the presence of muffled marsh sediments had no effect on timing of molting (Mann-Whitney $U$-test, $\mathrm{p}=0.43$ ). The median day of molting of megalopae in dishes with FSW was 12.0 (mean $=13.8$, $\mathrm{SD}=6.9$ ), and in dishes with both FSW and muffled sediment it was $12.5 \mathrm{~d}$ (mean $=14.6, \mathrm{SD}=10.1$ ). This suggests that the muffled sediments did not provide a tactile cue for molting in the field.

\section{DISCUSSION}

Our short-term field experiment provides strong evidence that natural cues greatly affect metamorphosis (molting) of crab megalopae, by inducing molting between 1 and $3 \mathrm{~d}$ after initial exposure. Both natural seawater overlying a marsh and natural marsh sediments dramatically affected timing of molting, compared to molting of sibling megalopae maintained in the laboratory. In fact, the magnitude of the response, as indicated by proportion molting, was greater than that seen in laboratory experiments (O'Connor 1991, O'Connor \& Gregg unpubl.). However, Christy (1989) also observed that sediments collected adjacent to adult burrows stimulated substantially earlier molting of Uca pugilator megalopae in the lab. The dramatic response of larvae to cues in the field compared with molting of siblings in the lab (Fig. 3) strongly suggests that larvae in the lab were in fact delaying metamorphosis (Pechenik 1990), rather than simply developing at a slower rate. Even though daytime air temperatures in the field became rather high, average water temperature was similar to that in which megalopae in the laboratory were maintained. Therefore, temperature differences between the laboratory and the field were not great, and probably did not accelerate molting of megalopae in the field.

The question arises as to the identity of the cues in nature. Two types of cues were important in stimulating molting: cues in the water and cues associated with benthic sediments. Water-soluble cues could have been derived from benthic sediments, marsh grass, or adult fiddler crabs inhabiting the marsh. Marsh grass is an unlikely cue, based on testing of leachates from Spartina in the laboratory $1 \mathrm{O}^{\prime}$ Connor \& Gregg unpubl.). It is likely that soluble cues from either conspecific adults or natural marsh sediments, or both, were effective in stimulating molting. In laboratory studies, cues derived from adult crabs significantly affect timing of molting of fiddler crab larvae (Christy 1989, O'Connor 1991, O'Connor \& Gregg unpubl.). In addition, substances associated with natural marsh sediments, rather than sediment particles themselves, may represent a contact-dependent cue for megalopae. Sediments without natural organisms and mole- 
cules (i.e. muffled marsh sediments in FSW) were not effective at stimulating molting in the laboratory.

Blue crab megalopae also molt sooner when exposed to potential habitat cues in the laboratory. Megalopal molting is advanced by exposure to estuarine seawater compared with offshore seawater (Wolcott \& De Vries 1994), and soluble materials leached from seagrasses are particularly effective at stimulating molting (Forward et al. 1994, 1996). The present study provides additional evidence that crab megalopae molt in response to chemical cues derived from adult habitats.

Benthic invertebrate larvae are known to utilize a variety of environmental cues to locate and metamorphose in suitable adult habitat. Hydrodynamic processes influence larval delivery and behavior at a variety of spatial scales (Eckman et al. 1983, Butman 1987). Surface characteristics may also serve as important tactile cues for larvae (Rittschof et al. 1984, Wethey 1986). There is ample evidence that larvae actively explore such surfaces after contact (Mullineaux \& Butman 1991. Walters 1992). In addition to their welldocumented role in crustacean biology, chemical cues have been shown important in many benthic groups, including polychaetes (Pawlik et al. 1991) and bivalves (Turner et al. 1994), even under simulated natural flow regimes. While we are not able to rank the relative importance of these cues in the present study, the strong differential response under field conditions to our manipulations suggests that chemical cues are critical to the settling larvae of benthic invertebrates.

The present study represents a new approach to the study of cues stimulating metamorphosis of invertebrate larvae. The caging technique allows control of larval age at exposure to cues, and manipulation of the source of the cues to which they are exposed. Our technique also ensures that equal numbers of larvae are exposed to different potential habitat cues. Other field experiments, primarily dealing with larval choice of settlement site, rely on chance transport of planktonic larvae to experimental sites, and must assume that larvae have full access to different experimental substrata. Even in studies in which larvae are pelagic for short periods and can be tracked directly by human observers, e.g. relatively large ascidian larvae (Olson 1985, Stoner 1990), researchers are unable to control larval abundance or delivery to field substrata. The success of the present caging study should open new avenues of field experimentation on larval metamorphosis.

Acknowledgements. We are very grateful to our students Amanda Gregg, Kerry Cudmore McCarthy, David Crino, and Danielle Cigliano for thesr assistance in the laboratory and the field. We thank Richard B. Forward, Jr, Jan Pechenik, and an anonymous reviewer for their comments on the manuscript. We also thank the staff of Demarest Lloyd State Park for allowing us to set up our odd-looking experiment in the park.

\section{LITERATURE CITED}

Butman CA (1987) Larval settlement of soft-sediment invertebrates: the spatial scales of pattern explained by active habitat selection and the emerging role of hydrodynamical processes. Oceanogr Mar Biol A Rev 25:113-165

Christy JH (1989) Rapid development of megalopae of the fiddler crab Uca pugilator reared over sediment: implications for models of larval recruitment. Mar Ecol Prog Ser 57 $259-265$

Eckman JE (1983) Hydrodynamic processes affecting benthic recruitment. Limnol Oceanogr 28:241-257

Eggleston DB, Armstrong DA (1995) Pre- and post-settlement determinants of estuarine Dungeness crab recruitment. Ecol Monogr 65:193-216

Fernandez M, Iribarne O, Armstrong D (1993) Habitat selection by young-of-the-year Dungeness crab Cancer magister and predation risk in intertidal habitats. Mar Ecol Prog Ser 92:171-177

Forward RB Jr, De Vries MC, Rittschof D, Frankel DAZ. Bischoff JP, Fisher CM, Welch JM (1996) Effects of environmental cues on metamorphosis of the blue crab Callinectes sapidus. Mar Ecol Prog Ser 131:165-177

Forward RB Jr, Frankel DAZ, Rittschof D (1994) Molting of megalopae from the blue crab Callinectes sapidus: effects of offshore and estuarine cues. Mar Ecol Prog Ser 113: $55-59$

Herrnkind WF, Butler MJ IV (1986) Factors regulating postlarval settlement and juvenile microhabitat use by spiny lobsters Panulirus argus. Mar Ecol Prog Ser 34:23-30

Mense DJ, Wenner EL (1989) Distribution and abundance of early life history stages of the blue crab, Callinectes sapidus, in tidal marsh creeks near Charleston, South Carolina. Estuaries 12:157-168

Mullineaux LS, Butman CA (1991) Initial contact, exploration and attachment of barnacle (Balanus amphitrite) cyprids settling in flow. Mar Biol 110:93-103

NOAA (1995) Tide tables, high and low water predictions, east coast of North and South America, including Greenland. US Dept of Commerce, Washington, DC

O'Connor NJ (1991) Flexibility in timing of the metamorphic molt by fiddler crab megalopae Uca pugilator. Mar Ecol Prog Ser 68:243-247

O'Connor NJ (1993) Settlement and recruitment of the fiddler crabs Uca pugnax and $U$. pugilator in a North Carolina, USA, salt marsh. Mar Ecol Prog Ser 93:227-234

Olson RR (1985) The consequences of short-distance larval dispersal in a sessile marine invertebrate. Ecology 66: $30-39$

Oith RJ, van Montfrans $J$ (1987) Utilization of a seagrass meadow and tidal marsh creek by blue crabs Callinectes sapidus. I. Seasonal and annual variations in abundance with emphasis on post-settlement juveniles. Mar Ecol Prog Ser 41:283-294

Pawlik JR, Butman CA, Starczak VAR (1991) Hydrodynamic facilitation of gregarious settlement of a reef-building tube worm. Science 251:421-424

Pechenık JA (1990) Delayed metamorphosis by larvae of benthic marine invertebrates: Does it occur? Is there a price to pay? Ophelia 32:63-94

RIttschof D, Branscomb ES, Costlow JD (1984) Settlement and behavior in relation to flow and surface in larval barnacles, Balanus amphitrite Darwin. J Exp Mar Biol Ecol 82: $131-146$

Stoner DS (1990) Recruitment of a tropical colonial ascidian: relative importance of pre-settlement vs post-settlement processes. Ecology 71:1682-1690 
Turner EJ, Zimmer-Faust RK, Palmer MA, Luckenbach M, Pentcheff ND (1994) Settlement of oyster (Crassostrea virginica) larvae: effects of water flow and a water-soluble chemical cue. Limnol Oceanogr 39:1579-1593

Walters LJ (1992) Field settlement locations on subtidal marine hard substrata: Is active larval exploration involved? Limnol Oceanogr 37:1101-1107

This article was submitted to the editor
Wethey DS (1986) Ranking of settlement cues by barnacle larvae: influence of surface contour. Bull Mar Sci 39: 393-400

Wolcott DL, De Vries MC (1994) Offshore megalopae of Callinectes sapidus: depth of collection, molt stage and response to estuarine cues. Mar Ecol Prog Ser 109: $157-163$

Manuscript first received: July 17, 1996

Revised version accepted: November 15, 1996 